\title{
Özel Eğitim Kurumlarında Çalışan Kadın Özel Eğitim Öğretmenlerinin Tükenmişlik Düzeylerinin İncelenmesi
}

DOI: $10.26466 /$ opus. 822363

\author{
Gülhan Dinç $c^{*}$ - M. Zeki İlgar** \\ *Uzman Psikolojik Danışman ve Rehber Öğretmen, Gaziantep/Türkiye \\ E-Posta: gulhan.dinc67@gmail.com \\ ORCID: $0000-0002-6139-8767$ \\ ${ }^{* *}$ Dr. Öğr. Üyesi, Biruni Üniversitesi, Eğitim Fakültesi, İstanbul/Türkiye \\ E-Posta: zilgar@biruni.edu.tr \\ ORCID: $\underline{0000-0002-5516-0752}$
}

\section{Öz}

Bu araştırmada, resmi ve özel özel eğitim kurumlarında çalışan kadın özel eğitim öğretmenlerinin, tükenmişlik düzeylerinin bazı demografik değişkenler açısından incelenerek, farklılaşıp farklılaşmadığının tespiti amaçlanmıştır. Araştırma, taramaya dayalı betimsel modelde desenlenmiştir. Örneklemini, 2017-2018 eğitim-öğretim yılında Gaziantep il merkezi ve ilçelerindeki özel eğitim kurumlarında görev yapmakta olan 225 kadın özel eğitim öğretmeni oluşturmaktadır. Araştırma verileri araştırmacı tarafindan hazırlanan "Kişisel Bilgi Formu" ve Maslach Tükenmişlik Envanteri aracıliğg ile elde edilmiştir. Araştırma için toplanan verilerin analizinde SPSS 24.0 programı kullanılmıştır. Tanımlayıcı istatistik teknikleri ile değişkenlere ilişkin ortalama, standart sapma, frekans ve yüzdelik değerler bulunmuştur. Bulguların incelenmesinde; Bă̆ımsız Örneklem TTesti, Kolmogorov-Smirnov Testi, Post-Hoc; Tukey Testi, Scheffe Testi, Games-Howell Testi, Tek Yönlü Varyans Analizi (Anova) ve Pearson Korelasyon Analizlerinden faydalanılmıştır. Araştırma sonucunda; "Duygusal Tükenmişlik" puanlarının medeni durum, yaş ve hizmet süresine göre farklılaşmadı̆̆̆l, "Duyarsızlaşma" puanlarının medeni durum ve hizmet süresine göre farklılaşmadı̆̆̆ , yaşa göre farklılaştı̆̆̆ı, "Kişisel Başarı" puanlarının yaşa ve hizmet süresine göre farklılaştı̆̆l, medeni duruma göre farklılaşmadığı sonuçlarına ulaşılmıştır. Bulgular literatür ışığııda tartışılmış ve ortaya çıkan sonuçlar yorumlanmıştır.

Anahtar Kelimeler: Özel Ĕ̆itim, Kadın Özel Ĕ̆itim Öğretmeni, Tükenmişlik. 


\title{
Examination of Burnout Levels of Woman Special Education Teachers Working in Private Educational Institutions
}

\begin{abstract}
In this study, it was aimed to investigate the levels of occupational burnout of woman special education teachers working in special education institutions by examining in terms of some demographic variables and to determine whether they differ or not. The research model is a descriptive exemplar based on scanning. The research samples constitutes 225 woman special education teachers who are working in Gaziantep province center and districts in 2017-2018 education year. The research data were obtained through the "Personal Information Form" and Maslach Burnout Inventory prepared by the researcher. SPSS 24.0 (Statistical Package For Social Sciences) program was used in the analysis of collected data. Mean, standard deviation, frequency and percentage values for variables were found by descriptive statistics techniques. Independent sample T-test, Kolmogorov-Smirnov Test, Post-Hoc; Tukey Test, Scheffe Test, Games-Howell Test, One Way Variance Analysis (Anova) and Pearson Correlation Analysis were used in the examination of findings. As a result of the research; "Emotional Burnout" scores do not differ according to marital status, age and duration of service, "Personal Achievement" scores differ according to age and duration of service, do not differ according to marital status, "Desensitization" scores differ according to age, do not differ according to marital status and duration of service. The findings were discussed and interpreted in light of the literature.
\end{abstract}

Keywords: Special Education, Woman Special Education Teacher, Burnout. 


\section{Giriş}

Bazı meslek grupları vardır ki tükenmişlik yaşama duygusunun yoğunluğuna göre risk grubuna dahil olmaktadırlar. Özel eğitim alanında çalışan kadın öğretmenler, "mesleklerini devam ettirirken baş etmek durumunda kaldıkları zorluk dereceleri" ve "toplumun kadına yüklediği rolleri yerine getirmekte yaşadıkları zorluklar" nedeniyle risk taşıyan gruptadırlar. Tükenmişlik doktor, hemşire, polis, yönetici ve öğretmenlerde diğer mesleklere göre nispeten daha fazla seyretmektedir (Gürbüz vd., 2007, s. 83).

Özipek (2006)'e, Oruç (2007)'a, Vizlı (2005)'ya ve Aslan (1996)'a göre tükenmişlik tanımlarında vurgulu olarak ifade edilenler; mesleki otizm, duygusal yorgunluk, hayata küskünlük, yüksek endişe ve kaygı, iş ve yaşam tutkusunun azalması, planlama ve organize eksikliği, motivasyon eksikliği, isteksizlik, başarısızlık, dengesizlik, çaresizlik, duyarsızlık, umutsuzluk, amaçsızlık, hedefsizlik, duygusal çöküş ve yıpranmışlıktır.

Kişilerin yetenek ve becerilerinin üzerinde beklenti düzeyi sebebiyle ortaya çıkan, zamanla baş edilmesi güç duygusal yüke dönüşen, motivasyon eksikliği ve yetersizlik hissi ile gelişen, yıpranma, umutsuzluk, bitkinlik, çökkünlük ve başarısızlık duyguları ile ifade edilen tükenmişlik; 1974'te Freudenberger'in "Journal of Social Issues" dergisinde yayımlanan makalesi ile literatüre girmiştir.

Bireylerin ruh sağlıklarını bilişsel, davranışsal ve duygusal olarak etkileyen tükenmişliğin nedenleri, belirtileri ve başa çıkma yöntemleri ile ilgili alanyazında çok sayıda araştırma bulunmaktadır (Çam, 1991; Çam, 1995; Girgin, 1995; Sabuncuoğlu, 1996; Işıkhan, 2004; Izgar, 2000; Izgar, 2001; Dursun, 2000; Tümkaya, 1996; Baysal, 1995).

Tükenmişlik, bireyi çok yönlü etkileyen olumsuz bir duygu durumudur. Tükenmişliği yaşayan bireyin etki gücü en yakınındakilerden en uzaktakilere doğru dairesel bir hızla ilerlemektedir. Eğitim boyutunda düşünüldügüunde tükenmişlik kişisel bir sorun olmaktan çıkıp orta ve uzun vadede toplumsal bir soruna dönüşmektedir.

Lazarus ve Lazarus (1994)'a göre kişilerin içinde bulunduğu koşullar ve koşulların ortaya çıkardığı olaylara karşı gösterilen tepkiler, toplumsal reflekslerimiz ve bunları yorumlama tarzımız, toplumsal kabul ve uyum, bireysel ve toplumsal stresin kaynaklarıdır. Baltaş ve Baltaş (1993)'a, 
Pearson ve Moomaw (2005)'a, Davis ve Wilson (2000)'a ve Pearson ve Hall (1993)'e göre öğretmenlik yüksek stres düzeyi olan mesleklerden biridir.

"Mesleki Yaşam" insan hayatına etkisi yoğun olan en önemli dönemlerdendir. Kadınlar ve iş yaşamı açısından bakıldığında ise özellikle incelenmeye değerdir. Meslek sahibi bireylerin çalışma ortamlarında karşılaştıkları ve ruh sağlıklarını olumsuz etkileyen faktörler strese sebebiyet vermekte ve meslek hayatına büyük umut ve hayaller ile başlayan çalışanlar tükenme duygusu yaşamaktadır. Olumlu duyguların ön planda olduğu çalışma ortamlarında, çalışanlar tükenmişlik duygusuyla baş edebilmekte, kendilerini iyi ve yeterli hissetmekte, işin kalitesi ve verimliliği artmaktadir.

Oruç (2007)'a göre kişisel ve mesleki yaşamlarında dengeyi oluşturmakta zorlanan kadın özel eğitim öğretmenleri bu süreçten olumsuz etkilenerek tükenmişlik yaşayabilmektedirler. Bu durum; öğrencilerine karşı olumsuz davranışlar, sınıf içi sorunlara hoşgörü ile yaklaşmada azalma, derse hazırlık davranışlarında azalma, düşük iş performansı, iş devamsızlıkları, işten ayrılmak isteme gibi istenmedik davranışlar oluşturabilir. Fiziksel sorunlar olarak istemsiz baş ağrıları, mide rahatsızlıkları yaşayabildikleri gibi ek olarak duygusal çöküş, tahammülsüzlük, hoşgörüsüzlük ve öğrencilere ve mesleğe yönelik olumsuz tutumlar göstermelerine sebep olabilmektedir.

Kadın özel eğitim öğretmenleri mesleki faaliyetlerinin yanısıra; çocuğun bakımı, sağlık durumu ve eğitim süreçlerinin takibi, eviçi roller ve sosyal yaşamın aktive edilmesi gibi kültürel kodların sadece kadına yüklediği sorumluluklardan dolayı ciddi deformasyona maruz kalmaktadır. $\mathrm{Bu}$ durum hem kişisel hem de mesleki yaşamlarında yetersizlik hissi doğurmakta, zamanla başedilmesi ve üstesinden gelinmesi zor, duygusal bir yüke dönüşebilmektedir. Yaşanılan bu süreç kendi yaşamları ve aile ortamlarındaki zorluklarla birleştiğinde ise hem bireysel yaşam kalitesini hem de mesleki yaşamının niteliğini negatif yönde etkilemektedir.

Öztürk ve Başgül (2020)'e ve İlgar ve İlgar (2016)'a göre yıkıcı davranış bozukluğu gibi dissosyetif alanda yer alan çocuklarla çalışıyor olmak, velilerin orantısız beklentileri, iş hayatı, ev hayatı ve aile hayatının sağlıklı dengesini oturtmaya çalışmak kadın özel eğitim öğretmenlerinde zararlı stres yükünü artırmakta, zamanla iyileşmesi beklenen stres yükü gerekli tedbirlerle desteklenmediğinde tükenmenin alt boyutları olan 
duyarsızlaşma, kişisel başarı ve duygusal tükenme boyutlarında yoğun yaşanmaktadır.

Görme, işitme, mental, fiziksel, yaygin gelişimsel, dil-konuşma ve öğrenme alanlarında sorun yaşayan, psikolojik ve sosyal davranış problemi olan özel gereksinimli çocuklarla çalışan öğretmenlerin "normal" çocuklarla çalışarak görev yapan öğretmenlerden daha çok yıprandıkları bilinmektedir. Bir yandan özel gereksinimli çocuklara yetersizliklerini giderecek eğitim faaliyetleri sürdürmek bir yandan da bu çocukları topluma entegre etmeye çalışmak oldukça zor bir iştir.

Oruç (2007)'a göre özel eğitim alanı konularının öğretilmesinin kolay olmayışı, kadın öğretmenlerin kendilerini yetersiz hissetmesi ve öğretme sürecinde mesleki tatmini yakalayamaması gibi nedenler tükenmişliği doğurmaktadır. Çocuğun gereksinim türü, davranış problemleri olup olmaması gibi faktörler; kadın özel eğitim öğretmenlerinin grup ve sınıf yönetimi tekniklerini kullanıp kullanmama durumu, usta öğreticinin olup olmaması, aynı meslekte çalışanlar ve ebeveynlerin tutumları gibi etmenler de siralanabilir.

573 sayılı özel eğitim yasası ve buna bağlı olarak çıkarılan özel eğitim hizmetleri yönetmeliği doğrultusunda yürütülen ayrımcılık, toplumdan soyutlama, ayrıştırma yerine fırsat eşitliği, tam katılım, bağımsız yaşam, ekonomik olarak kendine yetebilmeyi ifade eden özel eğitim; bireyin sosyal ve eğitim ihtiyaçlarını karşılamak, bağımlılığını azaltıp bağımsızlığını artırmak, diğer bireyler ile sağlıklı ilişkiler kurmasını, yaşam becerilerini geliştirmesini, hayata hazırlanmasını ve üretimde yer almasını sağlamak ve yeteneklerini geliştirmek için özel gereksinimli bireylerin gelişim alanlarını desteklemek ve eğitim gereksinimlerini karşılamak amacı ile özel olarak oluşturulmuş ortamlarda uzman eğitimciler tarafından kısa, orta ve uzun dönemli amaçlara ulaşmak için bireysel eğitim programının uygulandığ 1 süreçtir.

Diken (2017)'e göre çocukların farklılıkları üzerinde durmak yerine yapabileceklerine odaklanmak ve çocuğun dikkatini bu yöne çekmek özel eğitimin ruhuna en uygun eğitimdir. Risk, zedelenme ve herhangi bir engeli yüzünden normal gelişen bireyler için sunulan eğitim ortamlarından yararlanmaları güç olan bireylere gerekli bilgi ve beceri kazandırarak yetersizliğin engele dönüşmesini önleyen iyileştirici eğitimdir. 
Kadın özel eğitim öğretmenlerinin yeterliğini ve özel eğitimin niteliğini artırmak ve özel gereksinimi olan bireyleri topluma kazandırmak için kadın özel eğitim öğretmenlerinin tükenmişlik düzeylerinin incelenmesi önemlidir. Araştırmaya konu olan kadın özel eğitim öğretmenlerinin çeşitli demografik değişkenler açısından tükenmişliğinin incelenmesi, konuya ilişkin önlemler alınmasını ve kadın öğretmenlerin mesleklerine ilişkin algılamalarına pozitif katkı sağlayacak ve alanyazında var olan eksikliğe ilişkin ciddi veriler sunacaktır.

Araştırmanın genel amacı olan “Özel eğitim kurumlarında çalışan kadın özel eğitim öğretmenlerinin tükenmişlik seviyeleri nasıldır? Kadın özel eğitim öğretmenlerinin tükenmişlik seviyeleri; demografik değişkenler (medeni durum, yaş ve hizmet süresi) bakımından farklılaşmakta mıdır?" sorularının cevaplandırılabilmesi için alt problemleri içeren sorular şu şekilde sıralanmıştır.

- Kadın özel eğitim öğretmenlerinin medeni durum değişkenine göre tükenmişlik düzeyleri farklılaşmakta mıdır?

- Kadın özel eğitim öğretmenlerinin yaş değişkenine göre tükenmişlik düzeyleri farklılaşmakta mıdır?

- Kadın özel eğitim öğretmenlerinin hizmet süresi değişkenine göre tükenmişlik düzeyleri farklılaşmakta mıdır?

\section{Yöntem}

\section{Araştırmanın Modeli}

Gaziantep ilinde resmi ve özel özel eğitim kurumlarında çalışan kadın özel eğitim öğretmenlerinin tükenmişlik düzeylerinin ele alındığı çalışmada ilişkisel tarama modeli kullanılmış betimsel bir araştırma yapılmıştır. Araştırmada kadın özel eğitim öğretmenlerinin tükenmişlik düzeyleri; medeni durum, yaş ve kıdem gibi demografik değişkenler açısından incelenmiştir.

\section{Evren ve Örneklem}

Bu araştırmanın evreni; 2017-2018 öğretim döneminde, Gaziantep İli Şahinbey, Şehitkâmil, Nizip, İslâhiye, Araban, Nurdağı, Yavuzeli, Oğuzeli 
ve Karkamış İlçelerinde bulunan resmi ve özel özel eğitim kurumlarında çalışan 488 kadın özel eğitim öğretmenidir. Araştırmanın örneklem grubunu ise araştırmacı tarafından iletilen formları gönüllü olarak dolduran 225 kadın özel eğitim öğretmeni oluşturmaktadır.

\section{Veri Toplama Araçları}

Kişisel Bilgi Formu: Katılımcıların kişisel ve demografik özellikleri hakkında bilgi edinebilmek amacı ile 11 sorudan oluşan bu form araştırmacı tarafından hazırlanmıştır. "Kişisel Bilgi Formu" nda kadın özel eğitim öğretmenlerinin; yaş, medeni durum ve kıdem değişkenlerine yer verilmiştir.

Maslach Tükenmişlik Ölçeği: Tükenmişlik konusunda yapılan çalışmalarda en çok tercih edilen Maslach ve Jackson (1981) tarafından geliştirilen bu envanter Maslach Tükenmişlik Ölçeği (Maslach Burnout InventoryMBI) olarak alan yazınında yerini almıştır. Ölçeğin Türkçe'ye uyarlanması ile geçerlik ve güvenirlik çalışması Ergin (1992) tarafından yapılmıştir.

Duygusal Tükenme (Emotional Exhaustion) alt ölçeği (DT), meslek yaşamında, yoğun sorumluluk gerektiren, yüksek derecede psikolojik ve duygusal taleplere yüz yüze kalmaktan dolayı yaşanan enerjinin kaybını ifade etmektedir. Duygusal tükenme alt boyutunda 8 madde yer almaktadır. Yorgunluk, bıkkınlık ve duygusal enerjinin azalması ile ilgili 1., 2., 3., 6., 8., 13., 16. ve 20. maddeler bu boyutu ölçmeye yöneliktir.

Duyarsızlaşma (Depersonalization) alt ölçeği (D), kişilerin bakmak ve hizmet vermek ile sorumlu olduklarına karşı, duygudan arınmış bir halde, kişilerin biricik ve tek oldukları her bireyin eşsiz varlık olduklarını dikkate almaksızın tutumlar sergilemeleri ile ilgili kavramsallaştırılmıştır. 5., 10., 11., 15., 21. ve 22. maddelerin yer aldığ1 duyarsızlaşma alt boyutunda 6 madde bulunmaktadır.

Kişisel Başarı (Personal Accomplishment) Duygusunda Azalma alt ölçeği (KB), insanlarla iletişim gerektiren ve birebir görüşmelerin yoğun olduğu mesleklerde bireyin kendisini mesleğinde yetkin ve başarılı hissetmesi durumunu tanımlamaktadır. Bu ölçek 8 maddeden oluşmakta ve 4., 7., 9., 12., 14., 17., 18. ve 19. maddelerini içermektedir (Çam, 1992; Ergin, 1992; Izgar, 2000). 


\section{Verilerin Toplanması}

Uygulama yapılmadan önce her özel eğitim kurumunda kısa süreli toplantılar yapılarak araştırma konusu ve amacı hakkında gerekli bilgilendirme yapılmıştır. Veri toplama araçları katılımcılar sayısınca çoğaltılarak odalarında doldurmak üzere araştırmacı tarafından öğretmenlere elden verilmiştir. Doldurulan gönüllü onam formu, Kişisel Bilgi Formu ve Maslak Tükenmişlik Ölçeği araştırmacı tarafından teslim alınmıştır.

\section{Verilerin Çözümlenmesi ve Yorumu}

Araştırmada alt problemlerin çözümlenmesinde medeni durum, yaş ve hizmet süresi değişkenlerine göre gruplar arasında anlamlı bir fark olup olmadığının tespit edilmesi amacıyla "T" testi yapılmış ve "Tek Yönlü Varyans Analizi" (Anova) kullanılarak yorumlanmıştır. Buna göre araştırmada elde edilen bulguların yorumları yapılırken bağımsız değişkenlere göre anlamlı bir farkın bulunmadığı durumlarda yalnızca sonuçlar verilmiş, anlamlı farkın bulunduğu durumlarda ise bulgulara ait kısa değerlendirme ve yorumlara gidilmiştir. Farkın hangi gruplar arasında olduğunu belirlemek için çoklu karşılaştırmalar testi olan Tukey, Scheffe, Games-Howell testleri uygulanmıştır. İstatiksel çözümlemelerdeki anlamlılık düzeyi ana problem için $\mathrm{p}<.01$, alt problemler için $\mathrm{p}<.05$ olarak kabul edilmiştir.

\section{Bulgular}

\section{Demografik Bulgular}

Tablo 1. Araştırmaya Katılan Kadın Özel Eğitim Öğretmenlerinin Medeni Durum Değişkenine Göre Dă̆ılımları

\begin{tabular}{lll}
\hline Medeni Durum & $\mathbf{N}$ & $\mathbf{\%}$ \\
\hline Evli & 115 & 51,1 \\
Bekâr & 107 & 48,9 \\
Toplam & $\mathbf{2 2 5}$ & $\mathbf{1 0 0 , 0}$ \\
\hline
\end{tabular}


Tablo 1.'de görüldüğü gibi araştırmaya katılan kadın özel eğitim öğretmenlerinin medeni durum değişkenine göre \%51,1'i evli; \%48,9'u bekârdır.

Tablo 2. Araştırmaya Katılan Kadın Özel Ĕ̆itim Öğretmenlerinin Yaş Aralı̆̆ı Değişkenine Göre Dă̆ılımları

\begin{tabular}{lll}
\hline Yaş Aralı̆̆ $\mathbf{1}$ & $\mathbf{N}$ & $\mathbf{\%}$ \\
\hline $21-30$ & 133 & 59,1 \\
$31-40$ & 60 & 26,7 \\
$41-50$ & 21 & 9,3 \\
51 yaş ve üzeri & 11 & 4,9 \\
Toplam & 225 & $\mathbf{1 0 0 , 0}$ \\
\hline
\end{tabular}

Tablo 2.'de araştırmaya katılan kadın özel eğitim öğretmenlerinin yaş aralığ 1 değişkenine göre \%59,1'inin 21-30 yaş aralığında olduğu, \%26,7'sinin 31-40 yaş aralığında olduğu, \%9,3'ünün 41-50 yaş aralığında olduğu ve $\% 4,9^{\prime}$ unun 51 yaş ve üzeri yaş aralığında olduğu görülmektedir.

Tablo 3. Araştırmaya Katılan Kadın Özel Eğitim Öğretmenlerinin Hizmet Süresi Değişkenine Göre Dağılımları

\begin{tabular}{lll}
\hline Hizmet Süresi & $\mathbf{N}$ & $\mathbf{\%}$ \\
\hline $1-5$ & 122 & 54,2 \\
$6-10$ & 59 & 26,2 \\
$11-15$ & 21 & 9,4 \\
16 yıl ve üzeri & 23 & 10,2 \\
Toplam & 225 & $\mathbf{1 0 0 , 0}$ \\
\hline
\end{tabular}

Tablo 3.'te araştırmaya katılan kadın özel eğitim öğretmenlerinin hizmet süresi değişkenine göre \%54,2'sinin 1-5 yıl arası, \%26,2'sinin 6-10 yıl arası, $\% 9,4^{\prime}$ ünün 11-15 yıl ve \%10,2'sinin 16 yıl ve üzeri kıdemde oldukları görülmektedir.

\section{Araştırmanın Ana Problemine İlişkin Bulgular}

Veriler analize hazırlanırken incelendiğinde kayıp veri olmadığı görülmüştür. Boxplot grafiği kullanılarak aykırı olduğu tespit edilen 3 değer işlem dışı bırakılmış 222 araştırma katılımcısına ait verilerle incelemelere 
devam edilmiştir. Analizlere geçilmeden önce normallik testi yapılmıştır. Değişkenlere ilişkin normallik testi sonuçları Tablo 4.'de verilmiştir.

Tablo 4. Değişkenlere İlişkin Normallik Testi Sonuçları

\begin{tabular}{llll}
\hline & Duygusal Tükenme & Duyarsılaşma & Kişisel Başarı \\
\hline $\mathrm{N}$ & 222 & 222 & 222 \\
Kolmogorov-Smirnov & .093 & .166 & .071 \\
$\mathrm{P}$ & .000 & .000 & .009 \\
Çarpıklık & .538 & 1,143 & -.240 \\
\hline
\end{tabular}

Tablo 4. incelendiğinde duygusal tükenme, duyarsızlaşma ve kişisel başarı puan ortalamalarının Kolmogorov-Smirnov testi sonuçlarına göre normal dağılım göstermediği görülmektedir ( $\mathrm{p}<.05)$. Ancak çarpıklık katsayısı değerleri duygusal tükenme için .538, duyarsızlaşma için 1.143 ve kişisel başarı için -.240 bulunmuştur. Çarpıklık değerleri; Tabashnik'e göre -\%1,5 ve +\%1,5 ve ayrıca George and Marilyn'e göre de -\%2 ve +\%2 değerleri arasında olduğu için puanların normal dağılımdan önemli bir sapma göstermediği söylenebilir. Bununla birlikte sosyal bilimler-eğitim bilimleri gibi alanında yapılan araştırmalarda, mühendislik-tıp-fen gibi sayısal verilerle yapılan araştırmalar gibi normallik testinin katı bir bakış açısı ile aranmasını gerektirecek bir durum olmadığını hatırlamak gerekir. Değişkenler normal dağılım özelliği gösterdiğinden dolayı parametrik testlerin kullanılmasına karar verilmiştir. Bağımlı değişkenlere ait betimsel istatistikler Tablo 5.'de verilmiştir.

Tablo 5. Değişkenlere Ait Betimsel İstatistikler

\begin{tabular}{llllll}
\hline & $\mathrm{N}$ & $\mathrm{X}$ & Min & Max & Ss \\
\hline Duygusal Tükenme & 222 & 2,0709 & 1,00 & 4,50 & 0,71032 \\
\hline Duyarsızlaşma & 222 & 1,9685 & 1,00 & 3,83 & 0,48482 \\
\hline Kişisel Başarı & 222 & 3,7956 & 2,13 & 4,88 & 0,48852 \\
\hline
\end{tabular}

Tablo 5.'de Tükenmişlik ölçeğinin alt boyutları incelendiğinde en yüksek ortalamanın kişisel başarı $(X=3,7956)$ alt boyutunda olduğu, en düşük ortalamanın ise duyarsızlaşma $(X=1,9685)$ alt boyutunda olduğu bulunmuştur.

Değişkenler arasındaki ilişkiyi belirlemek amacıyla Pearson Korelasyon Analizi yapılmış elde edilen sonuçlar Tablo 6.' da belirtilmiştir. 
Tablo 6. Değişkenler Arasındaki İlişkiye Ait Pearson Korelasyon Analizi Sonuçları

\begin{tabular}{llll}
\hline & Duygusal Tükenme & Duyarsızlaşma & Kişisel Başarı \\
\hline Duygusal Tükenme & & & \\
Duyarsızlaşma & $.519^{* *}$ & & \\
Kişisel Başarı & $-.308^{* *}$ & $-.273^{* *}$ & \\
${ }^{* *} .01$ düzeyinde anlamlı & & & \\
\hline
\end{tabular}

Tablo 6. incelendiğinde duygusal tükenme ve duyarsızlaşma arasında $(\mathrm{r}=.519, \mathrm{p}<.01)$ orta düzeyde anlamlı ve pozitif bir ilişki vardır. Başka bir ifade ile duygusal tükenme puanları artarken duyarsızlaşma da artmaktadır. Duygusal tükenme ile kişisel başarı arasında $(\mathrm{r}=-.308, \mathrm{p}<.01)$ orta düzeyde anlamlı ve negatif bir ilişki vardır. Başka bir ifade ile duygusal tükenme puanları artarken kişisel başarı puanları azalmaktadır. Duyarsızlaşma ve kişisel başarı arasında $(\mathrm{r}=-.273, \mathrm{p}<.01)$ orta düzeyde anlamlı ve negatif bir ilişki bulunmuştur. Başka bir ifade ile duyarsızlaşma puanları artarken kişisel başarı puanları azalmaktadır.

Tükenmişliğin alt boyutları olan duygusal tükenme, kişisel başarı ve duyarsızlaşma bağımsız değişkenlerinin; medeni durum, yaş ve hizmet süresi ile aralarında regresyon analizleri yapılmış, collinearity-VIF değerlerinin 3 'ün altında olduğu görülmüş ve çoklu doğrusallık probleminin olmadığ tespit edilmiştir.

Özel eğitim kurumlarında çalışan kadın özel eğitim öğretmenlerinin duygusal tükenme, duyarsızlaşma ve kişisel başarı puan ortalamalarının medeni durumlarına göre farklılaşıp farklılaşmadığı ile ilgili yapılan Bağımsız Örneklem T - Testi sonucu Tablo 7.'de verilmiştir.

Tablo 7. Değişkenlere İlişkin Bağımsız Örneklem T - Testi Sonuçlarn

\begin{tabular}{llllllll}
\hline & $\begin{array}{l}\text { Medeni } \\
\text { Durum }\end{array}$ & $\mathbf{N}$ & $\mathbf{X}$ & Ss & Sd & t & p \\
\hline Duygusal & Evli & 115 & 2,1446 & 0,78580 & 213,604 & 1,621 & .107 \\
Tükenme & Bekâr & 107 & 1,9918 & 0,61292 & & & \\
Duyarsızlaşma & Evli & 115 & 1,9696 & 0,47888 & 220 & .035 & .972 \\
& Bekâr & 107 & 1,9673 & 0,49337 & & & \\
Kişisel Başarı & Evli & 115 & 3,8011 & 0,48860 & 220 & .173 & .863 \\
& Bekâr & 107 & 3,7897 & 0,49066 & & & \\
\hline
\end{tabular}

Tablo 7. incelendiğinde kadın özel eğitim öğretmenlerinin duygusal tükenme $\left(\mathrm{t}_{(213,604)}=1.621, \mathrm{p}>.05\right)$, duyarsızlaşma $\left(\mathrm{t}_{(220)}=.035, \mathrm{p}>.05\right)$ ve kişisel 
başarı $\left(\mathrm{t}_{(220)}=.173, \mathrm{p}>\right.$.05) puanlarının medeni duruma göre anlamlı bir farklılaşma göstermediği görülmektedir.

Özel eğitim kurumlarında çalışan kadın özel eğitim öğretmenlerinin duygusal tükenme, duyarsızlaşma ve kişisel başarı puanlarının yaş gruplarına göre farklılaşıp farklılaşmadığına ilişkin Tek Yönlü Varyans Analizi (Anova) yapılmıştır. Değişkenlere ilişkin betimsel istatistikler Tablo 8.'de verilmiştir.

Tablo 8. Değişkenlere İlişkin Betimsel İstatistikler

\begin{tabular}{lllll}
\hline & & $\mathbf{n}$ & $\mathbf{X}$ & Ss \\
\hline & $21-30$ & 131 & 2,0754 & 0,63864 \\
Duygusal & $31-40$ & 60 & 2,2083 & 0,86347 \\
Tükenme & $41-50$ & 20 & 1,8063 & 0,60218 \\
& $51+$ & 11 & 1,7500 & 0,62750 \\
\hline \multirow{3}{*}{ Duyarsizlaşma } & $21-30$ & 131 & 2,0038 & 0,48722 \\
& $31-40$ & 60 & 1,9611 & 0,53973 \\
& $41-50$ & 20 & 1,9000 & 0,33069 \\
Kişisel Başarı & $51+$ & 11 & 1,7121 & 0,28955 \\
& $21-30$ & 131 & 3,7281 & 0,46886 \\
& $31-40$ & 60 & 3,8125 & 0,52456 \\
& $41-50$ & 20 & 3,9625 & 0,44996 \\
& $51+$ & 11 & 4,2045 & 0,32726 \\
\hline
\end{tabular}

Tablo 8. incelendiğinde duygusal tükenme boyutunda en yüksek ortalamaya, 31-40 yaş arasında olan kadın özel eğitim öğretmenlerinin ( $X=$ 2,2083), duyarsızlaşma boyutunda en yüksek ortalamaya, 21-30 yaş arasında olan kadın özel eğitim öğretmenlerinin ( $X=2,0038)$, kişisel başarı boyutunda en yüksek ortalamaya, 51 ve üzeri yaşta olan kadın özel eğitim öğretmenlerinin $(X=4,2045)$ sahip olduğu görülmektedir.

Yaş düzeylerine göre duygusal tükenme, duyarsızlaşma ve kişisel başarı puanlarının farklılaşıp farklılaşmadığına ilişkin sonuçlar Tablo 9'da (Anova) verilmiştir.

Tablo 9. incelendiğinde yapılan analiz sonucuna göre duygusal tükenme $\left(\mathrm{F}_{(3-218)}=2,473, \mathrm{p}>.05\right)$ ve duyarsızlaşma $\left(\mathrm{F}_{(3-218)}=1,402, \mathrm{p}>.05\right)$ puanlarının yaşa göre farklılaşmadığı, bunlarla birlikte kişisel başarı $\left(\mathrm{F}_{(3-218)}=\right.$ 4,401, p<.05) puanlarının yaş düzeyine göre farklılaştığı bulunmuştur. Farklılığın kaynağını öğrenmek adına Post-Hoc testleri yapılmıştır. Duygusal tükenme boyutunun varyansı homojen dağıldığı için Scheffe testi 
yapılmıştır. Duyarsızlaşma ve kişisel başarı boyutlarının varyansları homojen dağılmadığı için Games-Howell testi yapılmıştır.

Tablo 9. Değişkenlerin Yaş Düzeyine Göre Anova Testi Sonuçları

\begin{tabular}{|c|c|c|c|c|c|c|c|}
\hline & & $\begin{array}{l}\text { Kareler } \\
\text { Toplamı } \\
\end{array}$ & Sd & $\begin{array}{l}\text { Kareler Orta- } \\
\text { laması }\end{array}$ & $F$ & p & $\begin{array}{l}\text { Anlamlı } \\
\text { Fark }\end{array}$ \\
\hline \multirow{3}{*}{$\begin{array}{l}\text { Duygusal } \\
\text { Tükenme }\end{array}$} & Gruplar Arası & 3,669 & 3 & 1,223 & 2,473 & ,063 & \\
\hline & Gruplar İçi & 107,838 & 218 & 0,495 & & & \\
\hline & Toplam & 111,508 & 221 & & & & \\
\hline \multirow{3}{*}{ Duyarsızlaşma } & Gruplar Arası & 0,984 & 3 & 0,328 & 1,402 & 243 & \\
\hline & Gruplar İçi & 50,962 & 218 & 0,234 & & & \\
\hline & Toplam & 51,946 & 221 & & & & \\
\hline \multirow{3}{*}{ Kişisel Başarı } & Gruplar Arası & 3,012 & 3 & 1,004 & 4,401 & 005 & $\sqrt{ }$ \\
\hline & Gruplar İçi & 49,730 & 218 & 0,228 & & & \\
\hline & Toplam & 52,741 & 221 & & & & \\
\hline
\end{tabular}

Duygusal tükenme boyutunda kadın özel eğitim öğretmenlerin yaş düzeylerine göre anlamlı fark olmadığı $(p=.063, p>.05)$ görülmüştür. Kişisel başarı boyutunda, 21-30 yaş ve 31-40 yaş arası kadın özel eğitim öğretmenleri ile 51 yaş ve üzeri kadın özel eğitim öğretmenleri arasında anlamlı fark ( $\mathrm{p}=.003, \mathrm{p}=.018, \mathrm{p}<.05)$ olduğu görülmüştür. Yaş1 51 ve üzeri olan kadın özel eğitim öğretmenlerinin, yaşı 21-30 ve 31-40 arasında olan kadın özel eğitim öğretmenlerine göre kişisel başarı hislerini anlamlı düzeyde kaybetmiş oldukları tespit edilmiştir. Duyarsızlaşma boyutunda, 21-30 yaş arası kadın özel eğitim öğretmenleri ile 51 yaş ve üzeri kadın özel eğitim öğretmenleri arasında anlamlı fark ( $\mathrm{p}=.039, \mathrm{p}<.05)$ olduğu görülmüştür. Yaşı 51 ve üzeri olan kadın özel eğitim öğretmenlerinin, yaşı 21-30 arasında olan kadın özel eğitim öğretmenlerine göre duyarlık hislerini anlamlı düzeyde kaybetmiş oldukları tespit edilmiştir.

Kadın özel eğitim öğretmenlerinin duygusal tükenme, duyarsızlaşma ve kişisel başarı puanlarının hizmet sürelerine göre farklılaşıp farklılaşmadığına ilişkin Tek Yönlü Varyans Analizi (Anova) yapılmıştır. Değişkenlere ilişkin betimsel istatistikler Tablo 10.'da verilmiştir.

Tablo 10. incelendiğinde duygusal tükenme boyutunda en yüksek ortalamaya, 11-15 yıl hizmet süresine sahip olan kadın özel eğitim öğretmenlerinin $(X=2,15)$, duyarsızlaşma boyutunda en yüksek ortalamaya, 1115 yıl hizmet süresine sahip olan kadın özel eğitim öğretmenlerinin $(X=$ 2,0083), kişisel başarı boyutunda en yüksek ortalamaya, 16 yıl ve üzeri 
hizmet süresine sahip olan kadın özel eğitim öğretmenlerinin $(X=4,0109)$ sahip olduğu görülmektedir.

Tablo 10. Değiş̧kenlere İlişkin Betimsel İstatistikler

\begin{tabular}{|c|c|c|c|c|}
\hline & & $\mathbf{N}$ & $X$ & Ss \\
\hline \multirow{4}{*}{$\begin{array}{l}\text { Duygusal } \\
\text { Tükenme }\end{array}$} & 1-5 Yil & 121 & 2,0579 & 0,69785 \\
\hline & 6-10 Y 11 & 58 & 2,1401 & 0,73190 \\
\hline & $11-15 Y_{11}$ & 20 & 2,1500 & 0,83074 \\
\hline & $16 Y_{11}$ ve üzeri & 23 & 1,8967 & 0,61429 \\
\hline \multirow{4}{*}{ Duyarsızlaşma } & $1-5 \mathrm{y} 1 \mathrm{l}$ & 121 & 1,9821 & 0,51226 \\
\hline & $6-10$ y1l & 58 & 1,9511 & 0,41182 \\
\hline & $11-15$ y1l & 20 & 2,0083 & 0,64089 \\
\hline & 16 yıl ve üzeri & 23 & 1,9058 & 0,35826 \\
\hline \multirow{4}{*}{ Kişisel Başarı } & $1-5 Y_{11}$ & 121 & 3,7211 & 0,49968 \\
\hline & 6-10 Yil & 58 & 3,8879 & 0,46399 \\
\hline & $11-15 Y_{11}$ & 20 & 3,7313 & 0,44662 \\
\hline & 16 Yıl ve üzeri & 23 & 4,0109 & 0,44739 \\
\hline
\end{tabular}

Hizmet süresine göre duygusal tükenme, duyarsızlaşma ve kişisel başarı puanlarının farklılaşıp farklılaşmadığına ilişkin sonuçlar Tablo 11.'de Anova çizelgesinde verilmiştir.

Tablo 11. Değişkenlerin Hizmet Süresine Göre Anova Testi Sonuçlan

\begin{tabular}{|c|c|c|c|c|c|c|c|}
\hline & & $\begin{array}{l}\text { Kareler Top- } \\
\text { lamı }\end{array}$ & Sd & $\begin{array}{l}\text { Kareler Orta- } \\
\text { laması }\end{array}$ & $F$ & p & $\begin{array}{l}\text { Anlamlı } \\
\text { Fark }\end{array}$ \\
\hline \multirow{3}{*}{$\begin{array}{l}\text { Duygusal } \\
\text { Tükenme }\end{array}$} & Gruplar Arası & 1,121 & 3 & 0,374 & 0,738 & 530 & \\
\hline & Gruplar İçi & 110,387 & 218 & 0,506 & & & \\
\hline & Toplam & 111,508 & 221 & & & & \\
\hline \multirow{3}{*}{ Duyarsızlaşma } & Gruplar Arası & 162 & 3 & 0,054 & 0,227 & 877 & \\
\hline & Gruplar İçi & 51,784 & 218 & 0,238 & & & \\
\hline & Toplam & 51,946 & 221 & & & & \\
\hline \multirow{3}{*}{ Kişisel Başarı } & Gruplar Arası & 2,315 & 3 & 0,772 & 3,336 & , 020 & $\sqrt{ }$ \\
\hline & Gruplar İçi & 50,426 & 218 & 0,231 & & & \\
\hline & Toplam & 52,741 & 221 & & & & \\
\hline
\end{tabular}

Tablo 11. incelendiğinde yapılan analiz sonucuna göre duygusal tükenme $\left(\mathrm{t}_{(3-218)}=0,738 \mathrm{p}>\right.$.05) ve duyarsizlaşma $\left(\mathrm{t}_{(3-218)}=0,227 \mathrm{p}>.05\right)$ puanlarının hizmet süresine göre farklılaşmadığı görülmektedir. Kişisel başarı $\left(\mathrm{t}_{(3-218)}=3,336 \mathrm{p}<.05\right)$ puanlarının ise hizmet süresine göre farklılaştı̆ğ bulunmuştur. Kişisel başarının kaynağını öğrenmek adına Post-Hoc testi 
yapılmıştır. Kişisel başarı boyutunun varyansı homojen dağıldığı için Tukey testi yapılmıştır. Kişisel başarı boyutunda 1-5 yıl arası hizmet süresi olan kadın özel eğitim öğretmenleri ile 16 yıl ve üzeri hizmet süresi olan kadın özel eğitim öğretmenleri arasında anlamlı fark $(\mathrm{p}=.043, \mathrm{p}<.05)$ olduğu bulunmuştur. Kadın özel eğitim öğretmenlerinin hizmet süresi uzadıkça kişisel başarı boyutunda düşük başarı hissi yaşadıkları tespit edilmiştir.

\section{Tartışma ve Sonuç}

Bu bölümde; resmi ve özel özel eğitim kurumlarında görev yapmakta olan kadın özel eğitim öğretmenlerinin tükenmişlik düzeyleri; medeni durum, yaş ve hizmet süresi değişkenlerine göre incelenmiş ve bulgular yorumlanmıştır. Tartışma ve yorumlar bulgular kısmındaki sıraya bağlı kalınarak yapılmıştır. Kadın özel eğitim öğretmenlerinin mesleki tükenmişlik düzeylerinin incelendiği araştırmaların çok sınırlı düzeyde olduğu görülmüştür. Bu nedenle araştırma sonuçları yorumlanırken bu sınırlılık dikkate alınmıştır. Kişisel Bilgi Formu (EK-1)'nda da dikkatleri çektiği gibi bu araştırma yalnızca, resmi ve özel özel eğitim kurumlarında çalışmakta olan "kadın özel eğitim öğretmenleri" ni içermesi bakımından bugüne kadar yapılmış diğer araştırmalardan ayrışmaktadır.

\section{Kadın Özel Ĕ̆itim Öğretmenlerinin Tükenmişlik Düzeylerinin "Medeni} Durum" Değişkenine Göre Farklılaşıp Farklılaşmadığını Gösteren Bulguların Tartışılması: Araştırmada, kadın özel eğitim öğretmenlerinin duygusal tükenme, duyarsızlaşma ve kişisel başarı puanlarının medeni duruma göre anlamlı bir farklılaşma göstermediği tespit edilmiştir.

Medeni durum değişkeninin ölçüldüğü başkaca araştırmalarda da benzer bulgulara ulaşılmıştır. Gündüz (2004)'e göre öğretmenlerde Tükenmişliğin Akılcı Olmayan İnançlar ve Bazı Mesleki Değişkenlere Göre Yordanması isimli araştırmada medeni durum değişkeninin tükenmişliğin üç alt boyutu üzerinde de anlamlı farklılaşmadığı bulgulanmıştır. Çavuşoğlu (2005)'na göre Endüstri Meslek Liselerinde Çalışan Öğretmenlerin Tükenmişlik Düzeyleri ile Bazı Kişisel Değişkenler Arasındaki İlişkinin incelendiği araştırmada medeni durum değişkeninin tükenmişliğin üç alt boyutu üzerinde de anlamlı farklılaşmadığı 
bulgulanmıştır. Oruç (2007)'a göre Özel Eğitim Alanında Çalışan Öğretmenlerin Tükenmişlik Düzeylerinin Bazı Değişkenler Açısından İncelenmesi (Adana İli Örneği) çalışmasında medeni durum değişkeninin tükenmişliğin üç alt boyutu üzerinde de anlamlı farklılaşmadığı bulgulanmıştır.

\section{Kadın Özel Ĕ̆itim Öğretmenlerinin Tükenmişlik Düzeylerinin "Yaş} Grubu" Değişkenine Göre Farklılaşıp Farkhlış̧madığını Gösteren Bulguların Tartışılması: (Gold, Robert ve Wright, 1991)'a göre yaşın tükenmişlikle, özellikle de kişisel başarı alt ölçek puanları ile ilişkili olduğu belirtilmektedir. Araştırmaya katılan kadın özel eğitim öğretmenlerinin "yaş grubu" değişkenine göre tükenmişlik ölçeğinden aldıkları puanlar incelendiğinde, duygusal tükenme boyutunda kadın özel eğitim öğretmenlerin yaş düzeylerine göre anlamlı fark olmadı ğı, duyarsızlaşma boyutunda yaşı 51 ve üzeri olan kadın özel eğitim öğretmenlerinin yaşı 21-30 arasında olan kadın özel eğitim öğretmenlerine göre duyarlık hislerini anlamlı düzeyde kaybetmiş oldukları; Yaşı 51 ve üzeri olan kadın özel eğitim öğretmenlerinin, yaşı 21-30 ve 31-40 arasında olan kadın özel eğitim öğretmenlerine göre kişisel başarı hislerini anlamlı düzeyde kaybetmiş oldukları tespit edilmiştir. Özmen (2001)'e göre Görme Engelliler Okullarında Görev Yapan Öğretmenlerin Tükenmişlik Düzeyleri çalışmasında yaş değiş̧keninin tükenmişliğin Duyarsızlaşma alt boyutunda anlamlı farklılaştığ 1 bulgulanmıştır. Şahin (2007)'e göre Öğretmenlerin Mesleki Tükenmişlik Düzeyleri çalışmasında yaş değişkeninin tükenmişliğin Duygusal Tükenme ve Duyarsızlaşma alt boyutlarında anlamlı farklılaştığı bulgulanmıştır. Yiğit (2007)'e göre Özel Eğitim Kurumlarında Çalışan Öğretmenlerin İş Doyumu Tükenmişlik ve Ruh Sağlık Düzeylerinin Çeşitli Değiş̧kenler Açısından İncelenmesi çalışmasında yaş değişkeninin tükenmişliğin alt boyutlarının tamamında anlamlı farklılaştığı bulgulanmıştır.

Bireylerde ilerleyen yaş ile birlikte sağlıksal sorunlar artar ve halsizliğin süreğen şekli olarak tükenmişlik sendromu ortaya çıkar (Sonnenschein vd., 2007, s. 487).

Tükenmişlik, duygusal tükenme ve duyarsızlaşma arasındaki etkileşimle kendini hissettirerek zamanla artan bir seyir izler (Sonnentag, 2005, s. 272). 
Araştırma bulgularından farklı olarak yaş düzeyinin artması ile tükenmişlik düzeyinin azaldığı yönünde çalışmalar da bulunmaktadır. Kişisel başarı alt boyutunda, yaşı 20-29 arasında olanların 40 yaş ve üzeri olanlara göre daha çok tükenmişlik yaşadığı tespit edilmiştir. Sağlık çalışanlarının, özel eğitim öğretmenlerinin, okul yöneticilerinin, polislerin, öğretmenlerin tükenmişlikleri konulu yapılan çalışmalarda yaşın artmasıyla birlikte tükenmenin azaldığını saptanmıştır. Çimen (2007)'e göre İlköğretim Öğretmenlerinin Tükenmişlik Yaşantıları ve Yeterlik Algıları çalışmasında yaş değişkeni ve tükenmişlik arasında ters yönlü bir ilişki bulgulanmıştır.

Birçok okul öncesi ve sınıf öğretmenlerinin emekli olduktan sonra yaygın olarak özel eğitim kurumlarında görev yapmakta oldukları bilinen bir husustur. Yaş arttıkça duyarsızlaşmanın artması ve kişisel başarının azalması bu durum ile yorumlanabilir.

\section{Kadın Özel Eğitim Öğretmenlerinin Tükenmişlik Düzeylerinin "Hizmet} Süresi" Değişkenine Göre Farklılaşıp Farklılaşmadı̆̆ını Gösteren Bulguların Tartışılması: Duygusal tükenme ve duyarsızlaşma puan ortalamalarının hizmet süresine göre farklılaşmadığı görülmektedir. Araştırma bulgularımız tükenmişlik ile hizmet süresinin kişisel başarı alt ölçek puanları ile ilişkili olduğunu göstermektedir. Kişisel başarı puanlarının ise hizmet süresine göre farklılaştığ 1 bulunmuştur. Kişisel başarı boyutunda 1-5 yıl arası hizmet süresi olan kadın özel eğitim öğretmenleri ile 16 yıl ve üzeri hizmet süresi olan kadın özel eğitim öğretmenleri arasında anlamlı fark olduğu bulunmuştur. Kadın özel eğitim öğretmenlerinin hizmet süresi uzadıkça kişisel başarı boyutunda düşük başarı hissi yaşadıkları tespit edilmiştir. Oruç (2007)'a göre Özel Eğitim Alanında Çalışan Öğretmenlerin Tükenmişlik Düzeylerinin Bazı Değişkenler Açısından İncelenmesi (Adana İli Örneği) araştırmasında meslekte 1-5 yıl arası görev yapan öğretmenlerin tükenmişlik düzeyleri ile 11 yıl ve üzeri görev yapan öğretmenlerin duygusal tükenme ve duyarsızlaşma alt boyutlarında anlamlı bir fark bulunamamışken kişisel başarı alt boyutunda mesleğe yeni başlayanların lehinde anlamlı bir fark bulunmuştur.

Yalçın (2011) yılında yapmış olduğu öğretmenlerin tükenmişlikleri ile ilgili bir araştırmasında mesleki kıdemin duygusal tükenme, duyarsızlaşma ve kişisel başarı düzeyleri üzerindeki temel etkisinin anlamlı olmadığını tespit etmiştir. 
Birçok okul öncesi ve sınıf öğretmenlerinin emekli olduktan sonra özel eğitim kurumlarında görev yapmakta oldukları bilinen bir husustur. Hizmet süresi arttıkça kişisel başarının azalması da aynı bağlamda değerlendirilebilir.

Kadın özel eğitim öğretmenlerinin görev süreleri arttıkça mesleki doyum, yıpranmışlık, aile ve yakınlarına vakit ayıramama düşüncesi ve yaşın ilerlemesi ile birlikte daha konforlu bir yaşam düşüncesi öne çıkmaktadır. Araştırma sonuçlarında yer alan yaş ve kıdem değişkenlerinin kişisel başarı ve duyarsızlaşmayı artırması Erikson'un 8 aşamalı psiko-sosyal gelişim kuramınının 7. gelişim dönemi "üretkenlik karşısında durağanlaşma, 30-60 yaş" ve 8. gelişim dönemi "benlik bütünlüğü karşısında umutsuzluk, 60+ yaş" ile açıklanabilir. 7. Dönem tam bir geçiş dönemidir ve taban ya da tavan yapma şeklinde görülmesi yüksektir. Yetersizliği olan birey ve aileleri ile çalışmak ikircikli duyguların yaşanmasına sebebiyet vermektedir. Memnuniyet ve usanç duygusu bu meslekte en çok yaşanan duygulardır. Bu olasıklar, üretkenlik ve yaratıcılığın artması veya tam tersi durgunlaşma, çöküşe geçme şeklindedir. Huzur ve pişmanlık arasında yaşanan çatışma ve "keşke"lerle yaşamaya devam eden, geçmişte yaşadıklarından pişmanlık duyan depresif ruh hali ile anlatılabilir (Gençtanırım-Kurt ve Çetinkaya, 2017, s. 213-215).

Özipek (2006)'e ve Tuğrul ve Çelik (2002)'e göre yaş ve tükenmişlik konusunda yapılan araştırmaların sonuçlarını incelendiğinde yaşlı çalışanların genç çalışanlardan daha fazla tükenmişlik semptomları gösterdiği yaşlılarda, işe geç gelmelerin, izinsiz gelmemelerin, sebepsiz izin almaların, işin niteliğinde bozulma gibi olumsuz durumların yaşı ileri olanlarda daha fazla görüldügü ve bu durumun tükenmişliğin kişisel başarı alt boyutlarında ciddi bir soruna neden olduğu ortaya çıkarılmıştır.

Başaran (1999)'a göre tükenmişliğin ilk belirtilerinin görüldüğü, ikaz lambası gibi işlev gören en önemli alt boyutlardan biri olan duyarsızlaşma; insanlarla iletişimin aktif olduğu, duygusal yoğunluğun fazlaca yaşandığı meslek gruplarında görülür. Kendilik bilincininin yapıtaşı olan duygusal kaynakların yitirilmesi; bakış açısının esnekliğini kaybederek katılaşması, insanlardan uzaklaşıp yanlızlık arayışına girilmesi toplumdan soyutlanma çabasıdır.

Baltaş ve Baltaş (1993)'a göre tükenmişliğin sonuçları incelendiğinde yaşlı çalışanların mesleklerine gösterdikleri fedakârlık duygusunda 
azalma ve emekliliğe ayrılma düşüncesi de tükenmişliğin belirtileri arasındadır. Bu yaşlar hesaplaşmanın yapıldığı yaşlardır. Kişiler gençlik çağının heyacanını geride bırakmış, toplumdaki statüsünü oturtmuştur. Bu konum gençliğinde özendiği "yer"den aşağıda ise iç hesaplaşma, çevreye ve kendine yönelik suçlama sebep arayışlarına girilir.

Araştırma sonucunda; "Duygusal Tükenmişlik" puanlarının medeni durum, yaş ve hizmet süresine göre farklılaşmadığı, "Kişisel Başarı" puanlarının yaşa ve hizmet süresine göre farklılaştığı, "Duyarsızlaşma" puanlarının yaş değişkenine göre farklılaştığı sonuçlarına ulaşılmıştır. 


\section{EXTENDED ABSTRACT}

\section{Examination of Burnout Levels of Woman Special Education Teachers Working in Private Educational Institutions \\ Gülhan Dinç - M. Zeki İlgar \\ MONE - Biruni University}

There are some occupational groups that are included in the risk group according to the intensity of the feeling of burnout. Women teachers working in the field of special education are in the risk group because of "the degree of difficulty they have to cope with while continuing their profession" and "the difficulties they experience in fulfilling the roles that society imposes on women".

What is emphasized in the definitions of burnout; occupational autism, emotional fatigue, resentment, high anxiety and worry, decreased passion for work and life, lack of planning and organization, lack of motivation, reluctance, failure, instability, helplessness, insensitivity, hopelessness, aimlessness, aimlessness, emotional collapse and wear and tear. Burnout is a negative emotional state that affects the individual in many ways. The influence power of the individual experiencing burnout progresses in a circular speed from the closest to the farthest. When considered in terms of education, burnout ceases to be a personal problem and turns into a social problem in the medium and long term. "Professional Life" is one of the most important periods that have an intense impact on human life. From the perspective of women and business life, it is especially worth examining.

The factors that professional individuals encounter in their working environments and that negatively affect their mental health cause stress, and employees who start their professional life with great hopes and dreams experience a feeling of exhaustion. In work environments where positive emotions are at the forefront, employees can cope with the feeling of burnout, feel good and sufficient, and increase the quality and productivity of their work. 
Female special education teachers, who have difficulty in creating a balance in their personal and professional lives, may experience burnout by being negatively affected by this process. This situation; Negative behaviors towards students can cause undesirable behaviors such as a decrease in tolerance for classroom problems, decrease in lesson preparation behaviors, low job performance, absenteeism from work, and wanting to leave work. As physical problems, they may experience involuntary headaches and stomach disorders, as well as emotional collapse, intolerance and negative attitudes towards students and the profession. In addition to their professional activities, female special education teachers; It is exposed to serious deformation due to the responsibilities imposed only on women by cultural codes such as child care, monitoring of health status and education processes, domestic roles and activating social life.

This situation creates a feeling of inadequacy in both their personal and professional lives, and over time it can turn into an emotional burden that is difficult to cope with and overcome. When this process is combined with the difficulties in their own lives and family environments, it negatively affects both the quality of their individual life and the quality of their professional life. It is important to examine the burnout levels of female special education teachers in order to increase the qualifications of female special education teachers and the quality of special education and to reintegrate individuals with special needs into society.

In this study, it was aimed to investigate the levels of occupational burnout of woman special education teachers working in special education institutions by examining in terms of some demographic variables and to determine whether they differ or not. Examining the burnout of female special education teachers, who are the subject of the research, in terms of various demographic variables will contribute positively to taking precautions regarding the subject and to female teachers' perceptions of their profession.

The research model is a descriptive exemplar based on scanning. The research samples constitutes 225 woman special education teachers who are working in Gaziantep province center and districts in 2017-2018 education year. The research data were obtained through the "Personal Information Form" and Maslach Burnout Inventory prepared by the researcher. SPSS 24.0 (Statistical Package For Social Sciences) program was used 
in the analysis of collected data. Mean, standard deviation, frequency and percentage values for variables were found by descriptive statistics techniques. Independent sample T-test, Kolmogorov-Smirnov Test, Post-Hoc; Tukey Test, Scheffe Test, Games-Howell Test, One Way Variance Analysis (Anova) and Pearson Correlation Analysis were used in the examination of findings.

The questions containing the sub-problems of the research are listed as follows.

- Do female special education teachers' burnout levels differ ac-cording to the marital status variable?

- Do female special education teachers' burnout levels differ ac-cording to the age variable?

- Do female special education teachers' burnout levels differ ac-cording to the variable of duration of service?

Burnout levels of female special education teachers working in public and private private education institutions; were examined according to the variables of marital status, age and duration of service, and the findings were interpreted. As noted in the Personal Information Form (Annex-1), this study differs from other studies conducted so far in that it only includes "female special education teachers" working in public and private private education institutions.

In the study, it was determined that the emotional exhaustion, depersonalization and personal achievement scores of female special education teachers did not show a significant difference according to "marital status". Similar findings were obtained in other studies in which the marital status variable was measured.

When the scores of the female special education teachers who participated in the study from the burnout scale were examined according to the "age group" variable, it was found that there was no significant difference according to the age levels of the female special education teachers in the dimension of emotional exhaustion, in the depersonalization dimension, it was found that female special education teachers aged 51 and over lost their sense of sensitivity significantly compared to female special education teachers aged 21-30, it has been determined that female special education teachers aged 51 and over have lost their sense of personal 
accomplishment significantly compared to female special education teachers aged between 21-30 and 31-40.

The increase in personal success and depersonalization by the age and duration of service variables in the research results can be explained by the periods, which is the 7th developmental period of Erikson's 8-stage psycho-social development theory, "stagnation against productivity, 3060 years old" and 8th developmental period "despairness in the face of self-integrity, $60+$ age". The 7th period is a complete transitional period and it is mostly seen as a lowest or highest.

It is observed that the mean scores of emotional exhaustion and depersonalization do not differ according to the duration of service. Our research findings show that burnout and duration of service are associated with personal achievement subscale scores. It has been found that personal achievement scores differ according to the duration of service. In terms of personal achievement, it was found that there was a significant difference between female special education teachers with a duration of service period of 1-5 years and female special education teachers with a duration of service period of 16 years or more. It has been determined that the longer the duration of service of female special education teachers, the lower the feeling of achievement in the dimension of personal achievement. It is a known fact that many preschool and classroom teachers work in private education institutions after their retirement. As the duration of service increases, the decrease in personal success can be evaluated in the same context. As the duration of service of female special education teachers increases, the idea of professional satisfaction, weariness, and not being able to spare time for family and relatives come to the fore.

As a result of the research; "Emotional Burnout" scores do not differ according to marital status, age and duration of service, "Personal Achievement" scores differ according to age and duration of service, do not differ according to marital status, "Desensitization" scores differ according to age, do not differ according to marital status and duration of service. The findings were discussed and interpreted in light of the literature.

\section{Kaynakça / References}


Aslan, H. (1996). Tipta uzmanlık öğrencisi hekimlerde tükenme düzeyleri. Türk Psikiyatri Dergisi, 7(1), 39-45.

Baltaş, A., ve Baltaş, Z. (1993). Stres ve başa çıkma yolları. İstanbul: Remzi Kitabevi.

Başaran, B. I. (1999). Zihinsel, görme ve işitme özürlü çocuklara eğitim veren özel eğitim kurumlarında çalışan öğretmenlerin kişilik özelliklerinin belirlenmesi ve karşılaştırılması. Yayımlanmamış Doktora Tezi. Dokuz Eylül Üniversitesi, İzmir.

Baysal, A. (1995). Lise ve dengi okul öğretmenlerinde meslekte tükenmişliğe etki eden faktörler. Yayımlanmamış Doktora Tezi. Sosyal Bilimler Enstitüsü, Dokuz Eylül Üniversitesi, İzmir.

Çam, O. (1991). Hemşirelerde tükenmişlik sendromunun araştırlması. Yayımlanmamış Doktora Tezi. Sağlık Bilimleri Enstitüsü, Ege Üniversitesi, İzmir.

Çam, O. (1992). Tükenmişlik envanterinin geçerlik güvenirliğinin araştırılması. VII. Ulusal Psikoloji Kongresi Bilimsel Çalışmaları El Kitab1.

Çam, M. O. (1995). Tükenmişlik. İzmir: Saray Medikal Yayıncılık.

Çavuşoğlu, İ. (2005). Endüstri meslek liselerinde çalışan öğretmenlerin tükenmişlik düzeyleri ile bazı kişisel değişkenler arasındaki ilişki. Yayımlanmamış Yüksek Lisans Tezi. Sosyal Bilimler Enstitüsü, Abant İzzet Baysal Üniversitesi, Bolu.

Çimen, S. (2007). İlköğretim Öğretmenlerinin tükenmişlik yaşantıları ve yeterlik algıları. Yayımlanmamış Yüksek Lisans Tezi. Sosyal Bilimler Enstitüsü, Kocaeli Üniversitesi, Kocaeli.

Davis, J., ve Wilson, S. M. (2000). Principles efforts to empower teachers: Effectson teacher motivation and job satisfaction and stress. TTie Clearing House, 75(6), 349-357.

Diken, H. İ. (2017). Özel Eğitime Gereksinimi Olan Öğrenciler ve Özel Eğitim. Ankara: Pegem Akademi.

Dursun, S. (2000). Öğretmenlerde tükenmişlik ile yükleme biçimi, cinsiyet, eğitim düzeyi ve hizmet süresi değişkenleri arasındaki yordayıcı ilişkilerin incelenmesi. Yayımlanmamış Yüksek Lisans Tezi. Sosyal Bilimler Enstitüsü, Karadeniz Teknik Üniversitesi, Trabzon.

Ergin, C. (1992). Doktor ve hemşirelerde tükenmişlik ve maslach tükenmişlik ölçeği'nin uyarlanması. VII. Ulusal Psikoloji Kongresi Bilimsel Çalışmaları. Ankara: Türk Psikologlar Derneği Yayınları, 143-154. 
Gençtanırım-Kurt, D., ve Çetinkaya, E. (2017). Kişilik kuramları. Ankara: Pegem Akademi.

Girgin, G. (1995). İlkokul öğretmenlerinde mesleki tükenmişliğin gelişimini etkileyen değişkenlerin analizi ve bir model önerisi (İzmir İli Kırsal ve Kentsel Yöre Karşılaştırması). Yayımlanmamış Doktora Tezi. Sosyal Bilimler Enstitüsü, Dokuz Eylül Üniversitesi, İzmir.

Gold, Y., Robert, A. R., ve Wright, C. R. (1991). The releationship of scores on the educational survey: a modified version of the maslach burnout inventory, the three teaching related variables for a sample of 132 beginning teachers. Educational and Psychological Measurement, 51, 429438.

Gündüz, B. (2004). Öğretmenlerde tükenmişliğin akılcı olmayan inançlar ve bazı mesleki değişkenlere göre yordanması. Yayımlanmamış Doktora Tezi. Sosyal Bilimler Enstitüsü, Çukurova Üniversitesi, Adana.

Gürbüz, H., Tutar, H., ve Başpınar, N. Ö. (2007). Burnout levels of executive lecturers: A comparative approach in three universities. Sosyal Bilimler Dergisi, 18, 65-85.

Işıkhan, V. (2004). Çalışma hayatında stres ve başa çıkma yolları. Ankara: Sandal Yayınları.

Izgar, H. (2000). Okul yöneticilerinin tükenmişlik düzeyleri nedenleri ve bazı etken faktörlere göre incelenmesi (Orta Anadolu örneği). Yayımlanmamış Doktora Tezi. Sosyal Bilimler Enstitüsü, Selçuk Üniversitesi, Konya.

Izgar, H. (2001). Okul Yöneticilerinde Tükenmişlik. Ankara: Nobel Kitabevi.

İlgar, M. Z., ve İlgar, S. C. (2016). Aile odaklı eğitim, kuramdan uygulamaya. İstanbul: İlgar Eğitim Danışmanlık Yayıncılık.

Lazarus, R. S., ve Lazarus, B. N. (1994). Passion and reason: Making sense of our emotions. New York: Oxford University Press.

Oruç, S. (2007). Özel eğitim alanında çalışan öğretmenlerin tükenmişlik düzeylerinin bazı değişkenler açısından incelenmesi (Adana ili örneği). Yayımlanmamış Yüksek Lisans Tezi. Sosyal Bilimler Enstitüsü, Çukurova Üniversitesi, Adana.

Özipek, A. (2006). Ortaöğretim okullarında görev yapan öğretmenlerde mesleki tükenmişlik düzeyi ve nedenleri. Yayımlanmamış YüksekLisans Tezi. Sosyal Bilimler Enstitüsü, Trakya Üniversitesi, Edirne.

Özmen, H. (2001). Görme engelliler okullarında görev yapan öğretmenlerin tükenmişlik düzeyleri. Yayımlanmamış Yüksek Lisans Tezi. Eğitim Bilimleri Enstitüsü, Gazi Üniversitesi, Ankara. 
Öztürk, M., ve Başgül, Ş. S. (2020). Çocuklarda dürtüsellik. İstanbul: Uçurtma Yayınları.

Pearson, L. C., ve Hall, B. C. (1993). Initial construct validation of the teaching autonomy scale. Journal of Educational Research, 86(3), 172-188.

Pearson, L. C., ve Moomaw, W. (2005). The relationship between teacher autonomy and stress. Work satisfaction, empowerment, and professionalism. Educational Reserach Quarterly, 29(1), 37-53.

Sabuncuoğlu, Z. (1996). Örgütsel psikoloji. Bursa: Ezgi Kitapevi Yayınları.

Sonnenschein, M., Sorbi, J. M., Lorenz, J. P., Schaufeli, W. B. ve Cora, M. J. M. (2007). Evidence that impaired sleep recovery may complicate burnout improvement independently of depressive mood. Journal of Psychosomatic Research, 62, 487-494.

Sonnentag, S. (2005). Burnout research: Addingan off-work and day-level perspective. First Publ. in: Work and Stress, 19(3), 271-275.

Şahin, E. (2007). Öğretmenlerin mesleki tükenmişlik düzeyleri. Yayımlanmamış Yüksek Lisans Tezi. Eğitim Bilimleri Enstitüsü, Gazi Üniversitesi, Ankara.

Tuğrul, B., ve Çelik, E. (2002). Normal gelişim gösteren çocuklarla çalışan anaokulu öğretmenlerinde tükenmişlik. Journal of Qafqaz University, 9, Spring, 203-213. Pamukkale Üniversitesi Eğitim Fakültesi Dergisi, 11(1), $1-18$.

Tümkaya, S. (1996). Öğretmenlerdeki tükenmişlik görülen psikolojik belirtiler ve başaçıkma davranışları. Yayımlanmış Doktora Tezi. Sosyal Bilimler Enstitüsü, Çukurova Üniversitesi, Adana.

Vızlı, C. (2005). Görme engelliler ilköğretim okullarında çalışan öğretmenlere normal ilköğretim okullarında çalışan öğretmenlerin tükenmişlik düzeylerinin karşılaştırılması, Üsküdar ilçesi örneği. Yayımlanmamış Yüksek Lisans Tezi. Eğitim Bilimleri Enstitüsü, Marmara Üniversitesi, İstanbul.

Yalçın, M. (2011). Özel eğitim kurumlarında çalışan eğitimcilerin tükenmişlik düzeylerinin empatik eğilim ve bazı değişkenler ile olan ilişkisi. Yayımlanmamış Yüksek Lisans Tezi. Sosyal Bilimleri Enstitüsü, Gaziantep Üniversitesi, Gaziantep.

Yiğit, A. (2007). Özel eğitim kurumlarında çalışan öğretmenlerin iş doyumu tükenmişlik ve ruh sağllk düzeylerinin çeşitli değişkenler açısından incelenmesi. Yayımlanmamış Yüksek Lisans Tezi. Sosyal Bilimler Enstitüsü, Niğde Üniversitesi, Niğde. 
Yıldırım, B. (2018). Endüstrileşme ve sosyal politika arasındaki ilişki üzerine bir değerlendirme. Ufkun Ötesi Bilim Dergisi, 18(1), 30-44.

Yolcuoğlu, İ. G. (2012). Türkiye'de sosyal politika ve sosyal hizmetlerin geliştirilmesi. Toplum ve Sosyal Hizmet, 23(2), 145-158.

\section{Kaynakça Bilgisi / Citation Information}

Dinç, G., ve İlgar, M. Z. (2021). Özel eğitim kurumlarında çalışan kadın özel eğitim öğretmenlerinin tükenmişlik düzeylerinin incelenmesi. OPUS-Uluslararası Toplum Araştırmaları Dergisi, 17(38), 52445270. DOI: 10.26466/opus. 822363 